\title{
PENCABUTAN HAK OPSI DALAM PERKARA WARIS \\ BAGI WARGA NEGARA INDONESIA YANG BERAGAMA ISLAM

\author{
Leliya
}

\author{
Fakultas Syariah dan Ekonomi Islam \\ IAIN Syekh Nurjati Cirebon \\ Jl. Perjuangan By Pass Sunyaragi Cirebon \\ Email: leliya12@yahoo.co.id
}

\begin{abstract}
Abstrak
Berdasar Penjelasan Umum UU No. 7 Tahun 1989 tentang Peradilan Agama bahwa bagi para pihak yang berperkara mengenai waris diberi hak opsi dalam menyelesaikan perkara tersebut. Pilihan hukum ini muncul karena adanya pluralisme hukum kewarisan di Indonesia, yaitu Hukum Kewarisan Adat, Hukum Kewarisan Barat, dan Hukum Kewarisan Islam. Namun, setelah berlakunya Undang-Undang No. 3 Tahun 2006, proses penyelesaian perkara kewarisan bagi umat Islam harus diselesaikan di Pengadilan Agama, sehingga tidak ada hak opsi lagi. Tulisan ini mengulas eksistensi hak opsi dalam UU PA dan perkembangan setelah berlakunya amandemen UU PA tahun 2006.
\end{abstract}

Kata kunci: UUPA, hak opsi, perkara waris, pencabutan hak opsi, Pengadilan Agama.

\begin{abstract}
Based on the General Explanation of Law No. 7 of 1989 on Religious Judiciary that for the litigants regarding inheritance be given the right to legal option to settle the case. Choice of law arises because of the inheritance law pluralism in Indonesia, namely Customary Inheritance Law, Western (Dutch) Inheritance Law and Islamic Inheritance Law. However, after the enactment of Law No. 3 In 2006, the process of the settlement of inheritance for Muslims should be completed in the Religious Court, so there is no further option rights. This paper reviews the existence of option rights in the Religious Judiciary Law and the developments after the enactment of the 2006 amendments.
\end{abstract}

Keywords: UUPA, option rights, heirs, revocation of option rights, Religious Courts. 


\section{Pendahuluan}

Manusia dalam perjalanannya di dunia mengalami tiga peristiwa penting, yaitu waktu ia dilahirkan, tumbuh tugas baru dalam dirinya yaitu ia akan mempunyai hak dan kewajiban. Setalah dewasa, akan kawin untuk membina keluarga yang akan menurunkan keturunan. Kemudian manusia pada suatu saat akan meninggalkan dunia. Setelah meninggal dunia, muncul perkara waris.

Terjadinya warisan adalah karena salah satu dari empat hal, yaitu (a) hubungan kerabat nasab, (b) hubungan perkawinan, (c) hubungan wala' ${ }^{, 1}$, dan (d) tujuan Islam (Jihatul Islam).

Di Indonesia sampai saat ini berlaku tiga sistem hukum, yaitu pertama sistem hukum adat yang didalamnya juga berisi aturan tentang hukum kewarisan adat, kedua sistem hukum Islam yang didalamanya terkandung aturan tentang hukum kewarisan Islam, dan ketiga sistem hukum barat yang didalamnya juga mengatur hukum kewarisan Barat. Keanekaragaman hukum tersebut bersumber pada ketentuan dalam pasal 163 IS (Indische Staatsregelings) jo pasal 131 IS yang membagi golongan penduduk menjadi tiga, yaitu golongan penduduk menjadi tiga, yaitu golongan Eropa, golongan Bumi Putra, dan golongan Timur Asing.

Sebelum berlakunya UndangUndang Peradilan Agama yaitu UndangUndang Peradilan Agama yaitu UndangUndang Nomor 7 Tahun 1989, Pengadilan Negeri memeriksa, memutus dan menyelesaikan perkara-perkara warisan untuk semua golongan penduduk. Setelah berlakunya UndangUndang Peradilan Agama tersebut kewenangan Peradilan Umum dalam memeriksa perkawa warisan beralih kepada Peradilan Agama bagi golongan penduduk yang menganut ajaran Islam.

\footnotetext{
${ }^{1}$ Yaitu hubungan antara bekas budak dan orang yang memerdekakannya apabila bekas budak itu tidak mempunyai ahli waris yang berhak menghabiskan seluruh harta warisan
}

Dalam penjelasan umum UndangUndang Nomor 7 Tahun 1989 tentang Peradilan Agama butir 2 alinea keenam dinyatakan bahwa :"Sehubungan dengan hal tersebut para pihak sebelum berperkara dapat mempertimbangkan untuk memilih hukum apa yang akan digunakan dalam pembagian waris".

Dalam ketentuan di atas berarti para pihak yang berperkara (beragama Islam) diberikan pilihan hukum oleh Undang-Undang yakni keleluasaan untuk memilih hukum warisan mana yang akan mereka pilih dalam penyelesaian pembagian harta warisan. Hal tersebut dapat menimbulkan konsekuensi yuridis yang menimbulkan yang menimbulkan berbagai penafsiran dalam beracara di Pengadilan Agama maupun Pengadilan Negeri yang berwenang menangani perkara waris, yaitu dapat bersifat mutlak yakni dengan pilihan hukum tersebut orang-orang yang beragama Islam dapat memberlakukannya didalam penyelesainnya perkara warisan baik di luar Peradilan maupun ketika dalam proses Peradilan, atau hal tersebut hanya dapat diberlakukan oleh orang-orang yang bergama Islam dalam penyelesaian perkara kewarisannya hanya ketika perkara tersebut belum berproses di Pengadilan.

Bagi umat Islam, berlaku hukum Islam sebagaimana tercantum dalam Instruksi Presiden Nomor 1 Tahun 1991 tentang Kompilasi Hukum Islam (KHI) buku II tentang kewarisan. Dalam pasal 171 dijelaskan bahwa yang dimaksud dengan hukum kewarisan adalah hukum yang mengatur tentang pemindahan hak pemilikan harta peninggalan (tirkah) pewaris, menentukan siapa-siapa yang berhak menjadi ahli waris dan berapa bagiannya masing-masing. Sedangkan mengenai berapa besarnya bagian ahli waris tercantum dalam pasal 176-191 KHI. Dan pengajuan perkara kewarisannya adalah Pengadilan Agama.

Bagi rakyat, umumnya berlaku KUHPerdata, sebagaimana diatur dalam 
Pasal 830-1130. Namun, mengenai pengertian kewarisan tidak disebutkan secara rinci hanya saja dalam pasal 830 dinyatakan bahwa "Pewarisan hanya berlangsung karena kematian". Dan bila terdapat perkara kewarisan, maka diajukan pada Pengadilan Negeri.

Ichtijanto berpendapat bahwa Undang-Undang Peradilan Agama memuat hukum Iblis karena memberi peluang kepada orang Islam untuk tidak menaati Allah dan Rasul-Nya bila para pihak yang berperkara memilih mengajukan perkara waris ke Pengadilan Negeri. Karena pemeriksaan oleh Pengadilan Negeri dengan sendiri memberlakukan hukum Adat atau Hukum Barat dan menyingkirkan Hukum Islam. $^{2}$

Secara umum Undang-Undang No. 7 Tahun 1989 tentang Peradilan Agama telah membawa perubahan yang sangat mendasar terhadap eksistensi Pengadilan Agama. Saat itu masih dikenal istilah "choice of law" atau pilihan hukum. Pilihan hukum disini dimaksudkan bahwa para pihak diperkenankan memilih dasar hukum yang akan dipakai dalam penyelesaian pembagian harta warisan, yang nantinya memberikan konsekuensi terhadap pengadilan mana yang berwenang untuk mengadili sengketa tersebut. Pilihan hukum di sini maksudnya sengketa tersebut dapat diajukan ke Pengadilan Negeri bila penyelesaiannya tunduk pada hukum Adat atau hukum Eropa (Civil Law) atau dapat diajukan ke Pengadilan Agama bila penyelesaiannya tunduk pada hukum Islam.

Dalam tataran praktek hal tersebut menimbulkan permasalahan ketika terjadi ketidaksepakatan di antara para pihak terhadap dasar hukum yang dipakai dalam penyelesaian tersebut, bahkan para pihak yang bersengketa menunjuk ke

${ }^{2}$ Panitia Seminar Nasional 10 Tahun Undang-Undang Peradilan Agama, 10 Tahun Undang-Undang Peradilan Agama, (Jakarta: Chasindo, 1999), hal. 90.
Pengadilan Negeri dan Pengadilan Agama secara bersamaan, sehingga terjadi dua tahap penyelesaian yakni di Pengadilan Agama maupun di Pengadilan Negeri dalam hukum acara terhadap perselisihan pilihan hukum tersebut harus menunggu fatwa atau bahkan upaya hukum kasasi ke Mahkamah Agung, yang memutuskan pengadilan mana yang berwenang untuk memeriksa, mengadili dan memutus sengketa tersebut, yang mana hal tersebut membutuhkan waktu yang tidak singkat. Sementara itu, di kedua lingkungan atau wilayah Pengadilan tersebut di atas saling mengklaim berwenang untuk menerima, memeriksa dan memutus perkara kewarisan tersebut. Akibat tersebut menjadi fenomena hukum tersendiri, yang pada akhirnya Asas peradilan cepat, sederhana dan biaya murah hanya sebatas slogan-slogan pemanis.

Undang-Undang No. 7 Tahun 1989 diubah dengan Undang-Undang No. 3 Tahun 2006 tentang Perubahan UU No. 7 Tahun 1989 tentang Pengadilan Agama diharapkan untuk memangkas "choice of law" dalam Hukum Kewarisan. Dalam Penjelasan Umum telah dinyatakan "Bahwa Para Pihak sebelum berperkara dapat mempertimbangkan untuk memilih hukum apa yang dipergunakan dalam pembagian warisan, dinyatakan dihapus". Menurut makna harfiah dari pernyataan dalam Penjelasan Umum tersebut adalah pilihan hukum sudah tidak dimungkinkan lagi.

Perubahan Undang-Undang No. 7 Tahun 1989 oleh Undang-Undang No. 3 Tahun 2006 tentang Perubahan UndangUndang No. 7 Tahun 1989 tentang Peradilan Agama, berpengaruh sangat besar baik terkait dengan eksistensi dari Pengadilan Agama maupun dari kewenangannya. Dimana kewenangan Pengadilan Agama diperluas. Sebagaimana dalam Pasal 49 menyatakan "Pengadilan Agama bertugas dan berwenang memeriksa, memutus dan menyelesaiakan perkara di tingkat 
pertama antara orang-orang yang beragama Islam dibidang: Perkawinan, Waris, Wasiat, Hibah, Wakaf, Zakat, Infaq, Shadaqah dan Ekonomi Syariah".

\section{Hak Opsi Dalam Perkara Kewarisan}

Pilihan hukum dapat diartikan sebagai opsi. Dalam kamus besar Bahasa Indonesia, opsi diartikan dalam tiga pengertian:

1. Tindakan memilih;

2. Kekuasaan/hak memilih kebebasan memilih;

3. Pilihan dari sejumlah alternatif. ${ }^{3}$

Opsi berasal dari Bahasa Belanda yaitu optie artinya: hak pilih; kebebasan untuk memilih; boleh pilih (mengenai kebangsaan/kewarganegaraan/warisan). ${ }^{4}$

Sebagaimana yang telah dijelaskan dalam bagian terdahulu, bahwa pinsip pilihan hukum (hak opsi) ini dapat ditemukan dalam Penjelasan Umum Undang-Undang Nomor 7 Tahun 1989 angka 2 alinea keenam yang berbunyi "Sehubungan dengan hal tersebut, para pihak sebelum berperkara dapat mempertimbangkan untuk memilih hukum apa yang akan dipergunakan dalam pembagian warisan". Dengan demikian, apabila dikaitkan dengan kompetensi absolut Peradilan Agama sebagaimana ditegaskan dalam pasal 49 ayat (1) huruf b yakni mengenai perkara di bidang kewarisan, maka dapat diperoleh suatu pengertian bahwa hak opsi dalam tulisan ini adalah suatu hak yang memberikan kebebasan bagi para pihak yang beragama Islam yang akan berperkara untuk memilih hukum apa yang akan dipergunakan dalam pembagian waris.

M. Yahya Harahap berpendapat bahwa yang dimaksud dengan hak opsi dalam perkara kewarisan adalah memilih

\footnotetext{
${ }^{3}$ Departemen Pendidikan dan Kebudayaan, Kamus Besar Bahasa Indonesia (Jakarta: Balai Pustaka, 1995), hal. 705.

${ }^{4}$ Lihat Andi Hamzah, Kamus Hukum (Jakarta: Ghalia Indonesia, 1986), hal. 421.
}

hukum kewarisan apa yang akan dipergunakan dalam menyelesaikan pembagian waris. ${ }^{5}$

Dari penjelasan umum tersebut bahwa bagi para pihak yang berperkara beragama Islam diberi hak opsi (hak pilih) dalam penyelesaian mengenai perkara waris. Pilihan hukum ini muncul karena adanya pluralisme hukum kewarisan yang berlaku di Indonesia yaitu hukum kewarisan adat, hukum kewarisan barat dan hukum kewarisan Islam.

Berpegang pada sebagian rumusan tersebut di atas, dapat dipertimbangkan untuk memilih hukum apa yang akan dipergunakan dalam hukum pembagian warisan, boleh jadi banyak orang yang menafsirkan bahwa pilihan hukum bagi penyelesaian perkara warisan orang Islam dibenarkan oleh Undang-Undang. Mereka yang menghendaki penyelesaian perkara kewarisan menurut hukum adat ataupun hukum barat merasa benar dan mempunyai dasar hukum untuk berperkara ke Pengadilan Negeri.

Dengan kata lain, dalam hal perkara waris khususnya waris Islam, Undang-Undang memberikan peluang kepada mereka untuk menentukan pilihan tata hukum warisan mana yang akan mereka pergunakan untuk penyelesainnya. Dalam mengajukan perkaranya apakah diajukan ke Pengadilan Agama yang menggunakan hukum Islam, dalam hal ini hukum positif yang dipergunakan adalah Intruksi Presiden Nomor 1 Tahun 1991 tentang Kompilasi Hukum Islam (KHI) ataukah ke Pengadilan Negeri yang menggunakan hukum barat (KUHPerdata) atau hukum adat.

Pengajuan tersebut dilakukan sebelum para pihak yang berperkara mengajukan perkaranya ke Pengadilan. Ketika para pihak telah mengajukan

${ }^{5}$ M. Yahya Harahap, Kedudukan, Kewenangan dan Acara Peradilan Agama Undang-Undang Nomor 7 Tahun 1989 (Jakarta: Pustaka Kartini, 1990), hal. 162. 
perkaranya tersebut ke salah satu badan peradilan, maka dianggap para pihak telah melakukan pilihan hukumnya terhadap badan peradilan yang telah dipilihnya itu.

Mengenai pilihan hukum tersebut, Mahkamah Agung mengeluarkan Surat Edaran Mahkamah Agung Nomor 2 Tahun 1990: "Perkara-perkara antara orang-orang yang beragama Islam dibidang kewarisan yang juga berkaitan dengan masalah pilihan hukum, hendaknya diketahui bahwa ketentuan pilihan hukum merupakan masalah yang terletak diluar badan peradilan, dan berlaku bagi mereka atau golongan rakyat yang hukum warisnya tunduk pada hukum adat dan atau hukum Islam atau tunduk pada hukum Perdata Barat dan atau hukum Islam, dimana mereka boleh memilih hukum adat atau hukum Perdata Barat (BW) yang menjadi wewenang Pengadilan Negeri atau memilih hukum Islam yang menjadi wewenang Pengadilan Agama.

Peradilan umum merupakan peradilan yang berwenang mengadili perkara-perkara perdata dan perkaraperkara pidana bagi rakyat pada umumnya. Dalam pasal 2 UndangUndang Nomor 7 Tahun 1989 menyebutkan bahwa Peradilan Agama merupakan salah satu pelaksana kekuasaan kehakiman bagi rakyat pencari keadilan yang beragama Islam mengenai perkara-perkara tertentu yang diatur dalam Undang-Undang ini.

Berdasarkan ketentuan di atas bahwa Peradilan Agama merupakan peradilan khusus bagi mereka yang beragama Islam. Kewenangan Peradilan Agama adalah seperti yang tercantum dalam pasal 49 ayat (1) Undang-Undang Nomor 7 Tahun 1989, yaitu: "Pengadilan Agama bertugas dan berwenang memeriksa, memutuskan dan menyelesaikan perkara-perkara di tingkat pertama antara orang-orang di tingkat pertama antara orang-orang yang beragama Islam dibidang (a) perkawinan, (b) kewarisan, wasiat dan hibah yang dilakukan berdasarkan hukum Islam, (c) wakaf dan sadaqah".

Berdasarkan pasal 50 UndangUndang Nomor 2 Tahun 1989 tentang Peradilan Umum bahwa "Pengadilan Negeri bertugas dan berwenang memeriksa, memutus dan menyelesaikan perkara pidana dan perkara perdata di tingkat pertama. Kekuasaan Pengadilan Negeri dalam perkara perdata meliputi semua sengketa tentang hak milik atau hak-hak yang timbul karenanya atau hakhak keperdataan lainnya, kecualu apabila dalam Undang-Undang ditetapkan pengadilan lain untuk memeriksa dan memutusnya. Setiap perkara perdata tidak hanya meliputi sengketa saja, tetapi di dalamnya mengandung pengertian masalah yang bersangkutan dengan yurisdiksi, yaitu tuntutan hak yang tidak mengandung sengketa.

Pernyataan berhak menyelesaikan perkara perdata, termasuk di dalamnya adalah perdata waris. Pengadilan Negeri merupakan pengadilan bagi rakyat pada umumnya. Jadi, dalam hal ini adalah tidak ada kekhususan golongan rakyat tertentu, semua golongan berhak mengajukan perkaranya ke Pengadiln Negeri termasuk perkara waris.

Hukum materil yang berlaku di Pengadilan Agama khususnya untuk perkara waris yaitu Instruksi Presiden Nomor 1991 tentang Kompilasi Hukum Islam (KHI) buku II, sedangkan Pengadilan Negeri menggunakan KUHPerdata (pasal 830-1130).

Kekuasaan pengadilan dibidang kewarisan, wasiat dan hibah, merupakan pemulihan kembali kekuasaan Pengadilan Agama di Jawa dan Madura sebagaiman diatur dalam Staatsblad 1937 Nomor 116 dan 610, atau ia merupakan usaha mempositifkan hukum kewarisan Islam tanpa "harus" diresepsi oleh hukum yang hidup sebagaimana tercermin dalam PP Nomor 45 Tahun 1957. Hal itu berarti terjadi penambahan kekuasaan pengadilan di lingkungan 
Pengadilan Agama, atau sebaliknya merupakan pengurangan kekuasaan pengadilan dalam lingkungan Peradilan Umum dalam perkara perdata tertentu. ${ }^{6}$

Kompetensi mutlak Peradilan Agama dibidang kewarisan ini tertera dalam pasal 49 Undang-Undang Nomor 7 Tahun 1989. Namun, mengingat kenyataan yang ada dalam masyarakat Islam setelah tahun 1937, yaitu tahun ditariknya kewenangan Peradilan Agama dibidang kewarisan dan memindahkannya ke Peradilan Negeri, terjadi dualisme kesadaran hukum. Sebagian orang-orang beragama Islam terutama di Jawa dan Madura, lebih suka soal-soal kewarisannya diselesaikan melalui hukum adat. Untuk menampung kenyataan ini, dalam penjelasan umum Undang-Undang Nomor 7 Tahun 1989 ditambahkan kalimat "Para pihak yang akan dipergunakan dalam pembagian warisan". Hal inilah yang secara umum dikenal sebagai pilihan hukum. ${ }^{7}$

Undang-Undang Nomor 7 Tahun 1989 tentang Peradilan Agama telah berlaku sejak diundangkan yaitu pada tanggal 19 Desember 1989. Pokok-pokok pikiran yang melandasi kehendak politik untuk diundangkannya Undang-Undang Nomor 7 Tahun 1989 adalah seperti yang tercantum dalam pertimbangan UndangUndang tersebut yang berjumlah lima butir:

$$
\begin{aligned}
& \text { a. bahwa Negara Republik } \\
& \text { Indonesia, sebagai negara } \\
& \text { hukum yang berdasarkan } \\
& \text { Pancasila dan Undang-Undang } \\
& \text { Dasar 1945, bertujuan } \\
& \text { mewujudkan tata kehidupan } \\
& \text { bangsa yang sejahtera, aman, } \\
& \text { tenteram, dan tertib }
\end{aligned}
$$

${ }^{6}$ Cik Hasan Bisri, Peradilan Agama di Indonesia, Jakarta, Raja Grafindo Persada, 1989, hal. 210.

${ }^{7}$ Bustanul Arifin, Pelembagaan Hukum Islam di Indonesia, Akar Sejarah, Hambatan dan Prospeknya (Jakarta: Gema Insani Press, 1996), hal. 99-100. b. bahwa untuk mewujudkan tata kehidupan tersebut dan menjamin persamaan kedudukan warga negara dalam hukum diperlukan upaya untuk menegakkan keadilan, kebenaran, ketertiban dan kepastian hukum yang mampu memberikan pengayoman kepada masyarakat

c. salah satu upaya untuk menegakkan keadilan, kebenaran, ketertiban dan kepastian hukum tersebut adalah melalui Peradilan Agama sebagaimana yang dimaksud dalam Undang-Undang Nomor 14 Tahun 1989 tentang Ketentuan-Ketentuan Pokok Kekuasaan Kehakiman

d. bahwa pengaturan tentang susunan, kekuasaan, dan hukum acara pengadilan dalam lingkungan Peradilan Agama yang selama ini masih beraneka didasarkan pada:

(1) peraturan tentang Peradilan Agama di Jawa dan Madura (Staatsblad tahun 1882 Nomor 152 dihubungkan dengan Staatsblad Tahun 1937 Nomor 116 dan 610);

(2) peraturan tentang Kerapatan Qadi dan Kerapatan Qadi Besar untuk sebagian Residensi Kalimantan Selatan dan Timur (Staatsblad Tahun 1937 Nomor 638 dan 639);

(3) peraturan pemerintah Nomor 45 Tahun 1957 tentang pembentukan pengadilan Agama/Mahkamah Syari`ah 
di luar Jawa dan Madura (Lembaran Negara Tahun 1957 Nomor 99), perlu segera diakhiri demi terciptanya kesatuan hukum yang mengatur Peradilan Agama dalam kerangka sistem dan tata hukum nasional berdasarkan Pancasila dan UndangUndang 1945.

e. bahwa sehubungan dengan pertimbangan tersebut dan untuk melaksanakan Undang-Undang Nomor 14 Tahun 1970 j.o. Undang-Undang Nomor 35 Tahun 1999 tentang KetentuanKetentuan Pokok Kekuasaaan Kehakiman, dipandang perlu menetapkan Undang-Undang yang mengatur susunan, kekuasaan, dan hukum acara pengadilan dalam lingkungan Peradilan Agama.

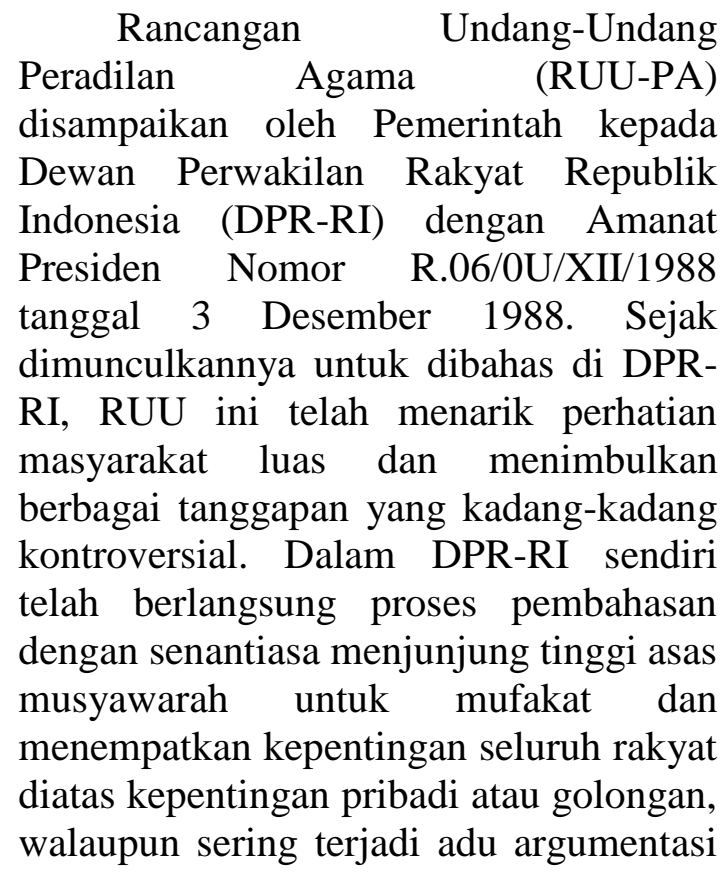

yang keras untuk mempertahankan pendiriannya masing-masing. ${ }^{8}$

Pemabahasan RUU-PA terbagi atas empat tingkat pembicaraan. Pembicaraan Tingkat Pertama diisi dengan penjelasan Pemerintah mengenai latar belakang diajukannya RUU-PA ke DPR-RI. Pembicaraan Tingkat Dua diisi dengan Pemandangan Fraksi-Fraksi dan jawaban Pemerintah atas Pemandangan Umum tersebut. Pembicaraan Tingkat Tiga adalah Penyampaian Pengantar Musyawarah dan Daftar Inventariasasi Masalah (DIM) dari tiap-tiap fraksi serta pembahan masalah-masalah yang cukup pelik. Pembicaraan Tingkat Empat berupa laporan Ketua Pansus, Penyampaian Pendapat Akhir FraksiFraksi, dan Pengambilan Keputusan dan Sambutan Pemerintah. ${ }^{9}$

Achmad Roestandi dan Muchjidin Effendie mengemukakan bahwa ketika dilakukan RUU-PA terdapat tiga pendapat tentang pilihan hukum. Pendapat pertama, menghendaki adanya pilihan hukum yang seluas-luasnya bagi para pencari keadilan dalam bidang perkawinan, kewarisan, hibah, wasiat, wakaf dan shadaqah. Pendapat kedua, menghendaki tidak adanya pilihan hukum bagi para pencari keadilan yang beragama Islam dalam keenam bidang itu. Pendapat ketiga, menghendaki adanya pilihan hukum bagi para pencari keadilan dalam bidang kewarisan, hibah dan wasiat saja. ${ }^{10}$

Setelah melalui perdebatan yang cukup tajam dikalangan para pembuat Undang-Undang, akhirnya disepakati bahwa untuk perkawinan, wakaf dan shadaqah Pengadilan Agama memiliki wewenang penuh/mutlak; untuk kewarisan; hibah dan wasiat terdapat

\footnotetext{
${ }^{8}$ Achamd Roestandi dan Muchjidin Effendie S., Komentar atas Undang-Undang Nomor 7 Tahun 1980 tentang Peradilan Agama dilengkapi Kompilasi Hukum Islam, (Bandung : Nusantara Press, 1991), hal. 9.

${ }^{9}$ Ibid, hal. 9.

${ }^{10}$ Ibid, hal. 16.
} 
pilihan hukum bagi para pencari keadilan. ${ }^{11}$

Pilihan hukum dimaksud, sebagaimana diuraikan sebelumnya, ialah hak untuk memilih hukum mana yang akan dipakai apabila terjadi sengketa mengenai warisan dimana antara para ahli warisnya terjadi ketidaksepakatan tentang hukum yang dipakai atau terjadi perbedaan agama antara para ahli waris. Pada Undang-Undang yang lama terdapat ketentuan tentang pilihan hukum untuk menyelesaikan perkara tentang waris. Namun, dalam Undang-Undang Nomor 3 tahun 2006 secara tegas dinyatakan bahwa tidak ada lagi pilihan hukum bagi penyelesaian sengketa mengenai waris. ${ }^{12}$

\section{Pencabutan Hak Opsi}

Undang-Undang No.3 Tahun 2006 tentang Perubahan atas Undang-Undang No.7Tahun 1989 tentang Peradilan Agama dinilai banyak kalangan telah banyak membawa perubahan yang sangat signifikan, baik mengenai eksistensi struktur keberadaan Peradilan Agama dengan jajaran lembaga negara lainnya, maupun mengenai materi- materi kompetensi yang di-emban oleh Peradilan Agama.

Pemantapan eksistensi Peradilan Agama secara struktural dapat dilihat dari munculnya Undang-Undang yang mendahuluinya yaitu Undang-Undang No.4 Tahun 2004 tentang Kekuasaan Kehakiman sebagai Undang-Undang organik atas Pasal 24 UUD 1945 pasca amandemen dengan menetapkan sistem satu atap (one roof system), yang berbunyi:

\section{Kekuasaan kehakiman merupakan kekuasaan yang merdeka}

untuk menyelenggarakan peradilan guna menegakkan hukum dan keadilan. Kekuasaan kehakiman dilakukan oleh

\footnotetext{
${ }^{11}$ Ibid, hal. 67.

12" Perubahan Kewenangan Pengadilan Agama Menurut Undang-Undang Nomor 3 Tahun 2006", Umat, 27 Juni 2008.
}

sebuah Mahkamah Agung dan badan peradilan yang berada di bawahnya dalam lingkungan peradilan umum, lingkungan peradilan agama, lingkungan peradilan militer, lingkungan peradilan tata usaha negara, dan oleh sebuah Mahkamah Konstitusi.

Berkaitan dengan proses penyelesaian perkara kewarisan bagi umat Islam pasca berlakunya UndangUndang No. 3 Tahun 2006 tersebut, harus diselesaikan di PengadilanAgama, sehingga tidak ada hak opsi lagi. Sebagaimana ditegaskan dalam penjelasan umum Undang-Undang No. 3 Tahun 2006 paragraf kedua yang berbunyi:

Dalam kaitannya dengan perubahan undang-undang ini pula, kalimat yang terdapat dalam penjelasan umum Undang-Undang Nomor 7 Tahun 1989 Tentang Peradilan Agama yang menyatakan: "Para pihak sebelum beperkara dapat mempertimbangkan untuk memilih hukum apa yang dipergunakan dalam pembagian warisan", dinyatakan dihapus.

Konsekwensi logis berlakunya Undang-Undang No.3 Tahun 2006 tersebutadalah Pengadilan Agama mempunyai kewenangan absolut atas penyelesaian sengketa waris yang subyek hukumnya adalah orang yang beragama Islam dan semua materi hukum kewarisan akan tunduk pada materi hukum yang ada di lingkungan Peradilan Agama. $^{13}$

Pencabutan Hak Pilih Hukum Waris(hak opsi) dalam perkara warisan ialah hak memilih hukum warisan apa yang akan dipergunakan dalalm menyelesaikan pembagian warisan. Penjelasan umum angka 1 alinea 2 UU Nomor 3 Tahun 2006 tentang Perubahan

\footnotetext{
${ }^{13}$ Ali Muhtarom, Menggali Hukum Kewarisan Islam Dalam Tata PerundangUndangan Peradilan Agama, http://www.ptasamarinda.net/pdf/Menggali\%20Hukum\%20Wari s\%20d\%20Indonesia.pdf.
} 
Atas UU No.7 Tahun 1989 tentang Peradilan Agama, bahwa kalimat yang terdapat dalam penjelasan umum UU Nomor 7 Tahun 1989 yang menyatakan : "Para pihak sebelum berperkara dapat mempertimbangkan untuk memilih hukum apa yang dipergunakan dalam pembagian warisan", dinyatakan dihapus. Sebab ditinjau dari segi pendekatan hukum Islam pemberian hak opsi itu kurang dapat dibenarkan, sebab seolaholah membuka pintu bagi penganut agama Islam untuk meninggalkan hukum waris Islam dan lebih mengutamakan nilai-nilai hukum waris asing.

Penghapusan hak opsi ini secara filosofis merupakan pengejawantahan dari salah satu azaz hukum waris Islam, yaitu Azas Ijbari atau Keharusan, kewajiban. Yang dimaksud Ijbari adalah bahwa dalam hukum kewarisan Islam secara otomatis peralihan harta dari seseorang yang telah meninggal dunia (pewaris) kepada ahli warisnya sesuai dengan ketetapan Allah SWT tanpa digantungkan kepada kehendak seseorang baik pewaris maupun ahli waris. Unsur keharusannya (ijbari/compulsory) terutama terlihat dari segi di mana ahli waris (tidak boleh tidak) menerima berpindahnya harta pewaris kepadanya sesuai dengan jumlah yang telah ditentukan oleh Allah. Oleh karena itu orang yang akan meninggal dunia pada suatu ketika, tidak perlu merencanakan penggunaan hartanya setelah ia meninggal dunia kelak, karena dengan kematiannya, secara otomatis hartanya akan beralih kepada ahli warisnya dengan bagian yang sudah dipastikan. Azas Ijbari ini dapat juga dilihat dari segi yang lain yaitu

a. Peralihan harta yang pasti terjadi setelah orang meninggal dunia.

b. Jumlah harta sudah ditentukan untuk masing-masing ahli waris.

c. Orang-orang yang akan menerima harta warisan itu sudah ditentukan dengan pasti yakni mereka yang mempunyai

hubungan darah dan perkawinan. $^{14}$

Hapusnya hak Opsi ini menurut penulis juga memberi efek positif bagi kepastian hukum antara para pihak yang bersengketa dimana memberi kejelasan tentang kewenangan badan peradilan mana yang akan memeriksa dan memutus perkara tentang sengketa hak milik atau hak keperdataan lainnya.

\section{Kesimpulan}

Berdasarkan penjelasan yang telah dipaparkan tersebut, maka dapat disimpulkan sebagai berikut:

Hak opsi dalam perkara waris, yaitu diatur dalam penjelasan umum butir 2 alinea keenam Undang-Undang Nomor 7 Tahun 1989 tentang Peradilan Agama: "Sehubungan dengan hal tersebut, para pihak yang berperkara dapat mempertimbangkan untuk memilih hukum apa yang akan dipergunakan dalam pembagian waris".

Pengadilan Agama berdasarkan pasal 49 ayat 1 Undang-Undang Nomor 7 Tahun 1989, berhak memeriksa dan menyelesaikan perkara waris bagi orangorang yang beragama Islam sesuai dengan kompetensi absolut dari badan peradilan tersebut dan Pengadilan Negeri berdasarkan pasal 50 Undang-Undang Nomor 2 Tahun 1986 tentang Peradilan Umum menentukan bahwa Pengadilan Negeri harus bertugas dan berwenang memeriksa, memutus dan menyelesaikan perkara pidana dan perdata ditingkat pertama.

Berkaitan dengan proses penyelesaian perkara kewarisan bagi umat Islam pasca berlakunya Undang-

\footnotetext{
${ }^{14}$ Asep Ridwan, Implementasi Perluasan Kompetensi Peradilan Agama Menurut Undangundang Nomor 3 Tahun 2006, http://www.pakalianda.go.id/gallery/artikel/200-implementasiperluasan-kompetensi-peradilan-agama-menurutundang-undang-nomor-3-tahun-2006.html.
} 
Undang No. 3 Tahun 2006 tersebut, harus diselesaikan di PengadilanAgama,sehingga tidak ada hak opsi lagi. Sebagaimana ditegaskan dalam penjelasan umum Undang-Undang No. 3Tahun 2006 paragraf kedua yang berbunyi:

Dalam kaitannya dengan perubahan undang-undang ini pula, kalimat yang terdapat dalam penjelasan umum Undang-Undang Nomor 7 Tahun 1989 tentang Peradilan Agama yang menyatakan: "Para pihak sebelum beperkara dapat mempertimbangkan untuk memilih hukum apa yang dipergunakan dalam pembagian warisan", dinyatakan dihapus.

\section{Saran}

Atas dasar kajian dari berbagai segi tentang ketentuan adanya prinsip pilihan hukum dalam Undang-Undang Nomor 7 Tahun 1989 tentang Peradilan Agama, maka perlu adanya perbaikan di masa datang, seperti:

Hak Opsi (Pilihan hukum) sebagaimana terdapat dalam Penjelasan Umum Undang-Undang Nomor 7 Tahun 1989 tersebut kiranya perlu dihilangkan, sehingga perkara dibidang kewarisan sebagaimana perkara-perkara tertentu dibidang lainnya menjadi kewenangan absolut Peradilan Agama.

Perlunya sosialisasi mengenai kewarisan khususnya bagi umat Islam apabila timbul masalah didalamnya, untuk mengajukan perkaranya ke Pengadilan Agama serta perlu didukung pula dengan peningkatan kesadaran hukum umat Islam itu sendiri untuk menyelesaikan masalah kewarisan menggunakan hukum Islam.

Undang-Undang No. 7 Tahun 1989 diubah dengan Undang-Undang No. 3 Tahun 2006 tentang Perubahan UU No. 7 Tahun 1989 tentang Pengadilan Agama diharapkan untuk memangkas "choice of law" dalam Hukum Kewarisan.Dalam kaitannya dengan permasalahan kewarisan, hal tersebut tidak begitu signifikan, karena tidak ada penjelasan bila terjadi permasalahan diantara ahli waris baik yang berbeda agama maupun yang tidak, kemudian yang mempermasalahkan pembagian harta warisan apakah menganut dan tunduk pada hukum islam maupun adat atau eropa, dalam perundangan tersebut tidak diberikan suatu solusi yang dapat menengahi persoalan yang telah mengakar meskipun undang-undang menyatakan pilihan hukum telah dihapus.

\section{Daftar Pustaka}

Arifin, Bustanul, Pelembagaan Hukum Islam di Indonesia, Akar Sejarah, Hambatan dan Prospeknya, Jakarta: Gema Insani Press, 1996.

Bisri, Cik Hasan, Peradilan Agama di Indonesia, Jakarta: Raja Grafindo Persada, 1989.

Departemen Agama RI, Analisis Putusan Badan Peradilan Agama, Jakarta, 2000.

Departemen Pendidikan dan Kebudayaan, Kamus Besar Bahasa Indonesia, Jakarta: Balai Pustaka, 1995.

Hamzah, Andi, Kamus Hukum, Jakarta: Ghalia Indonesia, 1986.

Harahap, M. Yahya, Kedudukan, Kewenangan dan Acara Peradilan Agama Undang-Undang Nomor 7 Tahun 1989, Jakarta: Pustaka Kartini, 1990.

Mahkamah Agung RI, Himpunan Putusan Mahkamah Agung Republik Indonesia tentang Kewenangan Mengadili, Jakarta, 1995.

Muhtarom, Ali, Menggali Hukum Kewarisan Islam Dalam Tata Perundang-Undangan Peradilan Agama, http://www.ptasamarinda.net/pdf/Menggali\%20Hu kum\%20Waris\%20d\%20Indonesia. pdf. 
Panitia Seminar Nasional 10 Tahun Undang-Undang Peradilan Agama, 10 Tahun Undang-Undang Peradilan Agama, Jakarta, Chasindo, 1999.

Ridwan, Asep, Implementasi Perluasan Kompetensi Peradilan Agama Menurut Undang-undang Nomor 3 Tahun 2006, http://www.pakalianda.go.id/gallery/artikel/200implementasi-perluasan-

kompetensi-peradilan-agamamenurut-undang-undang-nomor-3tahun-2006.html.

Roestandi, Achmad dan Muchjidin Effendie S., Komentar atas Undang-Undang Nomor 7 Tahun 1989 tentang Peradilan Agamadilengkapi dengan Kompilasi Hukum Islam, Bandung: Nusantara Press, 1991.

PERATURAN

PERUNDANGUNDANGAN

Undang-Undang Dasar 1945.

Undang-Undang Nomor 14 Tahun 1970 tentang Pokok-Pokok Kekuasaan Kehakiman.

Undang-Undang Nomor 1 Tahun 1974 tentang Perkawinan.

Undang-Undang Nomor 14 Tahun 1985 tentang Mahkamah Agung.

Undang-Undang Nomor 2 Tahun 1986 tentang Peradilan Umum.

Undang-Undang Nomor 7 Tahun 1989 tentang Peradilan Agama.

Kitab Undang-Undang Hukum Perdata (BW).

Instruksi Presiden Nomor 1 Tahun 1991tentang Kompilasi Hukum Islam (KHI). 